\title{
Genetic diversity and adaptability of two species of Mugilidae (Teleostei: Perciformes) of the Po river delta coastal lagoons
}

\section{Diversité et adaptabilité génétique de deux espèces de Mugilidae (Téléostéens perciformes) de lagunes côtières du delta du Pô}

\author{
Riccardo Papa ${ }^{\text {a }}$, Francesco Nonnis Marzano ${ }^{\mathrm{a}, *}$, Valeria Rossi ${ }^{\mathrm{b}}$, Gilberto Gandolfi ${ }^{\mathrm{a}}$ \\ ${ }^{a}$ Dipartimento di Biologia Evolutiva e Funzionale, University of Parma, Parco Area delle Scienze 11/A, 43100 Parma, Italy \\ ${ }^{b}$ Dipartimento di Scienze Ambientali, University of Parma, Parco Area delle Scienze 11/A, 43100 Parma, Italy
}

Received 31 July 2002; accepted 30 September 2002

\begin{abstract}
Molecular polymorphisms (allozyme and amplified fragment length polymorphisms (AFLP)) were investigated in the mullet specie's Liza ramada and Liza saliens to determine levels of genetic variability and assess possible correlations between the population genetic structure and the specie's adaptability to shallow water environments. The thinlipped (L. ramada) and the sharpnose ( $L$. saliens) mullets are diadromous species that enter coastal lagoons during early life stages to complete growth previous to sexual maturation. Bi-monthly samples $(n=30-50)$ were collected in the period 2000-2002 in different sites of the Sacca di Goro (Po river delta) and a nearby aquaculture lagoon (Valle Bertuzzi). Biochemical analyses were carried out by means of starch gel electrophoresis (SGE) on 24 genetic loci corresponding to 15 gene-enzyme systems. In addition, molecular species-specific AFLP (15 primer combinations) were obtained by means of capillary electrophoresis. The degree of allozyme variability determined at three polymorphic loci, GPI-A, GPI-B and G3PDH in L. saliens and L. ramada (polymorphic loci $P=0.08$; mean heterozygosity $H=0.010-0.022)$ and AFLP diversity $(P=0.110-0.430)$, seems lower than the one reported in the literature for ecologically similar teleost species. The identification of diagnostic alleles at GPI-A, G3PDH, AK-2, CK-A, CK-B, AAT, IDH, PGM-1, PGM-2 loci in the two mullet species was used for the taxonomic classification of L. saliens and L. ramada. Molecular taxonomy (allozyme and AFLP) demonstrated that the presence of small individuals inside the lagoons previously identified according to morphological characters has often been misinterpreted. The results are discussed in relation to the adaptive role of genetic variation and the migratory characteristics of Mugilidae.
\end{abstract}

(C) 2003 Éditions scientifiques et médicales Elsevier SAS and Ifremer/CNRS/IRD. All rights reserved.

\section{Résumé}

Le polymorphisme moléculaire (systèmes enzymatiques et la technique AFLP (amplified fragment length polymorphisms)) a été étudié chez deux espèces de mulets, Liza ramada et Liza saliens de manière à estimer la variabilité génétique et à vérifier les éventuelles corrélations entre la structure génétique de la population et l'adaptabilité des espèces en eaux peu profondes. Le mulet à lèvres fines $L$. ramada et le mulet à net pointu $L$. saliens sont des espèces diadromes qui pénètrent dans les lagunes côtières pendant les premiers stades de leur vie pour s'y nourrir et grandir avant d'atteindre la maturité sexuelle. Des prélèvements ont été effectués chaque deux mois de 2000 à 2002 à différentes stations de la « Sacca di Goro » (delta du Pô) et dans une lagune voisine utilisée pour l'aquaculture (Valle Bertuzzi). Les analyses biochimiques par électrophorèse sur gel d'amidon ont été conduites sur 24 locus génétiques correspondant à 15 systèmes gènes-enzymes. De plus, ont été réalisés des profils moléculaires (15 combinaisons primaires) par une électrophorèse capillaire s'appuyant sur la technique AFLP. Le degré de variabilité des systèmes enzymatiques déterminé aux trois locus polymorphiques GPI-A, GPI-B et G3PDH pour $L$. saliens et pour $L$. ramada $(P=0,08 ; H=0,010-0,022)$ et la diversité AFLP $(P=0,110-0,430)$ semble inférieur comparé aux données de la littérature portant sur des poissons écologiquement semblables. L'identification d'allèles caractéristiques aux locus des systèmes PGI-A, G3PDH, AK-2, CK-A, CK-B, AAT, IDH, PGM-1, PGM-2 pour les deux espèces a été utilisée pour la classification taxinomique. Cette taxinomie moléculaire prouve que la

\footnotetext{
* Corresponding author.

E-mail address: nonnis@biol.unipr.it (F. Nonnis Marzano).
} 
présence de petits individus dans la lagune, identifiés précédemment sur la base de caractères morphologiques, a souvent été mal interprétée. Les résultats sont discutés par rapport au rôle adaptatif de la diversité génétique et aux caractéristiques migratoires des Mugilidae.

(c) 2003 Éditions scientifiques et médicales Elsevier SAS and Ifremer/CNRS/IRD. Tous droits réservés.

Keywords: AFLP; Allozyme; Capillary electrophoresis; Liza spp.; Molecular polymorphisms

Mots clés : AFLP ; Systèmes enzymatiques ; Electrophorèse capillaire ; Liza spp. ; Polymorphisme moléculaire

\section{Introduction}

The thinlipped and the sharpnose mullets, respectively, Liza ramada and Liza saliens, are commercially important diadromous species in Italy. They enter coastal lagoons during early life stages to carry out the trophic phase previous to sexual maturation. Their cathadromous habit makes them exploited species in commercial fishing in the coastal lagoons of the Po river delta. Although some Mugilidae species have been investigated to determine phylogenetic inferences by means of allozyme and mitochondrial DNA, most of the attention was deserved to the genetic divergence of global populations of the striped mullet Mugil cephalus and congenerics (Crosetti et al., 1994; Rossi et al., 1998a, b). There is still a lack of data on the genetic variability of the more than 60 species belonging to 17 different genera of the Mugilidae family (Nelson, 1994).

It is noteworthy to remember that the genetic differentiation within and among populations is of major importance for the evolutive flexibility and conservation of species. In fact, it is well known that genetic variability is correlated with individual and relative fitness of the organisms, and their capacity to respond to environmental changes is quite enhanced in structured populations (Britten, 1996; David, 1998; Mitton, 1998; Tsitrone et al., 2001). Analysis of protein-coding loci still plays a prominent role in the description of intraspecific genetic diversity in natural fish populations (Ward and Grewe, 1994; Carvalho and Hauser, 1998; Parker et al., 1998). However, a vast array of molecular markers is nowadays available to describe population structure and systematic characters. Each marker has merits and demerits, therefore, evaluation of several types of markers is needed to assess temporal and spatial patterns of genetic variation in nature.

Among the variety of new methodologies, the amplified fragment length polymorphism (AFLP) is gaining attention among animal geneticists. AFLP generates hundreds of informative genetic markers with a high number of polymorphic loci. Although heterozygosity is hardly detectable (AFLP is a dominant marker), the method combines universal applicability with high powers of discrimination and reproducibility, and provides a valuable tool to study genetic relationships at both the intraspecific and the interspecific levels (Savelkoul et al., 1999; Seki et al., 1999).

In this paper, molecular polymorphisms (allozyme and AFLP) were investigated in the mullet species L. ramada and $L$. saliens to determine levels of genetic variability and assess possible correlations between the population genetic structure and the species adaptability to shallow water environments. The adaptive role of genetic variability has been hypothesized in many teleosts but never investigated in Liza species. As a matter of fact, recently Huang et al. (2001) suggested that natural selection may play a role in shaping allelic frequency changes during the migratory journey of the similar species $M$. cephalus. In particular, polymorphisms at the GPI-A locus can be useful for population discrimination.

Furthermore, it is noteworthy to observe that the thinlipped and sharpnose mullets cannot be distinguished merely by using morphometric and meristic characters, especially in the juvenile stages (Caldara et al., 1996). Molecular tools to assess the systematic status of migrating juveniles inside the Adriatic coastal lagoons, were therefore, applied and are herein presented. In the past, allozyme electrophoresis had been used for the identification and distinction of various mullet species but the results seem to be quite confused (Papasotiropoulos et al., 2001). Therefore, such additional markers as the AFLP were applied in this work. It must be remarked that application of AFLP markers to fishery science is very recent (Seki et al., 1999), and no AFLP data has ever been reported for any mullet species.

\section{Materials and methods}

\subsection{Study area and sampling locations}

Among the coastal lagoons of the Po river delta, the Sacca di Goro is a shallow-water embayment $\left(44^{\circ} 47^{\prime}-44^{\circ} 50^{\prime} \mathrm{N}\right.$ and $12^{\circ} 15^{\prime}-12^{\circ} 20^{\prime} \mathrm{E}$ ) deeply influenced by anthropogenic eutrophication and massive macroalgal growth which cause summer anoxia and dystrophy (Viaroli et al., 1999). The lagoon has an extension of about $26 \mathrm{~km}^{2}$ with flat bottom and an average depth of $1.5 \mathrm{~m}$. It is connected to a system of enclosed marginal lagoons which are used for fish-farming, and a relatively large $(1 \mathrm{~km}$ wide $)$ outlet.

The thinlipped and the sharpnose mullets $L$ ramada and L. saliens were caught between May 2000 and January 2002 by means of a $15 \mathrm{~m}$ trawling net in three sampling stations previously selected on the basis of different environmental conditions Fig. 1. Two stations inside the main embayment being characterized by relatively steady sediment (Ca' Romanina) or physical turbation of the benthic compartment (Spiaggina); one station (Pre Valle) is the only place in the Valle Bertuzzi separated from the fish farming area and without mullet restocking. The restocked population is a 


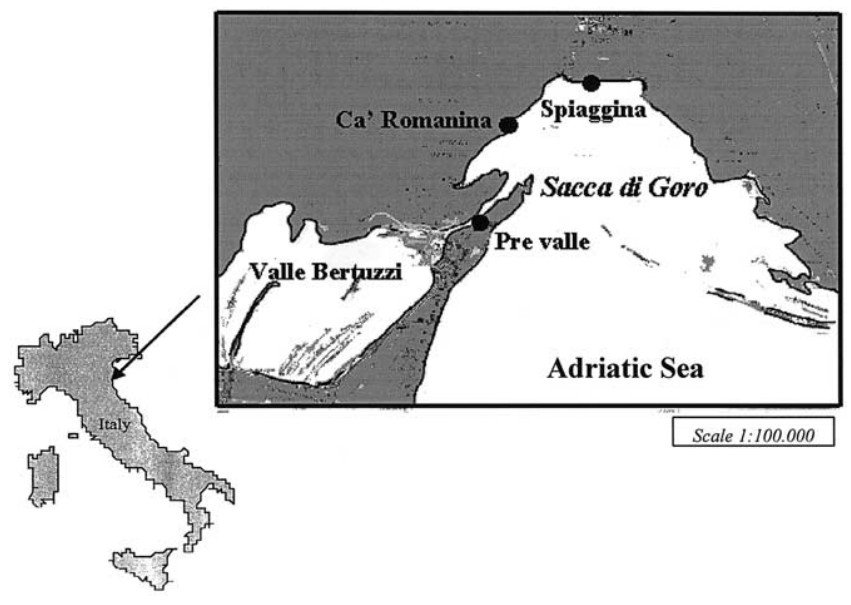

Fig. 1. Sampling stations in the Sacca di Goro, and in the connection channel of the aquaculture lagoon Valle Bertuzzi not influenced by mullet restocking.

land-locked population separated from natural migrating fish by means of artificial barriers. Sampling was carried out in the same sites at different times. A variable number of 30-50 individuals $(2.5-12 \mathrm{~cm}$ total length) were caught each time in each station (a total number of 280 and 60 fish were studied using allozymes and AFLP, respectively), transported with ice-packs and stored at $-80^{\circ} \mathrm{C}$ until electrophoresis and DNA extraction. A representation of sampling dates during 2001 and average total lengths of both species is illustrated in Fig. 2.

\subsection{Electrophoretic analyses}

Homogenates of epiaxial muscle, liver and eye were separately prepared by grinding $0.5-1 \mathrm{~g}$ of frozen tissue with
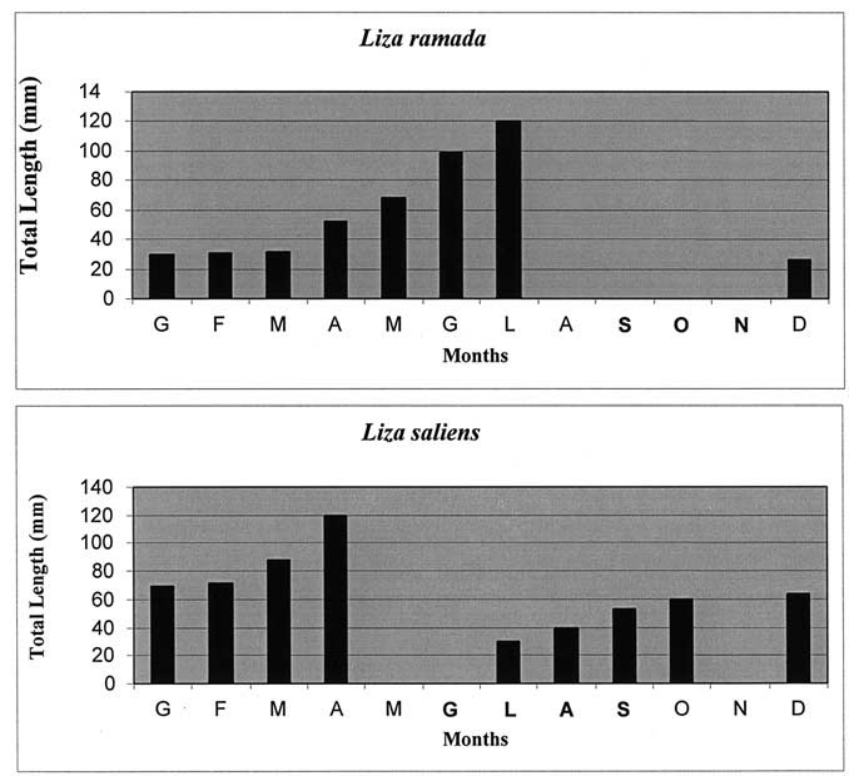

Fig. 2. Sampling dates during 2001 and trends of mean total lengths of $L$. saliens and $L$. ramada. Months in bold represent the reproductive period of each species.
Table 1

Gene-enzyme systems assayed in the different tissues of $L$. saliens and L. ramada, and polymorphic loci detected

\begin{tabular}{llll}
\hline Enzyme & Locus & Tissue & Variability \\
\hline Oxidoreductases & & & \\
Alcohol dehydrogenase & ADH & Muscle & Monomorphic \\
Glycerol-3-P dehydrogenase & G3PDH & Muscle & Polymorphic \\
Lactate dehydrogenase & LDH-A & Muscle & Monomorphic \\
& LDH-B & Liver & Monomorphic \\
& LDH-C & Eye & Monomorphic \\
Malate dehydrogenase & sMDH-A & Muscle & Monomorphic \\
& sMDH-B & Muscle & Monomorphic \\
Malic enzyme & ME & Muscle & Monomorphic \\
Isocitrate dehydrogenase & sIDH & Muscle & Monomorphic \\
Phosphogluconate dehydrogenase & PGDH & Liver & Monomorphic \\
Xanthine dehydrogenase & XDH & Liver & Monomorphic \\
Transferases & & & \\
Creatine kinase & CK-A & Muscle & Monomorphic \\
& CK-B & Muscle & Monomorphic \\
Adenylate kinase & AK-1 & Muscle & Monomorphic \\
& AK-2 & Muscle & Monomorphic \\
Phosphoglucomutase & PGM-1 & Muscle & Monomorphic \\
Hydrolases & PGM-2 & Muscle & Monomorphic \\
Esterase & & & \\
& EST-1 & Muscle & Monomorphic \\
Fumarate hydratase & EST-2 & Liver & Monomorphic \\
Isomerases & EST-3 & Liver & Monomorphic \\
Glucose-6-P isomerase & PEP & Muscle & Monomorphic \\
& FH & Muscle & Monomorphic \\
& & & \\
\hline & PGI-A & Muscle & Polymorphic \\
& PGI-B & Muscle & Polymorphic \\
\hline & & & \\
& & & \\
& & &
\end{tabular}

equal volumes of cold $0.25 \mathrm{M}$ Tris- $0.06 \mathrm{M}$ citrate buffer at $\mathrm{pH} 8.0$, and centrifuging at $12000 \mathrm{rpm}$ for $7 \mathrm{~min}$. The supernatant was then adsorbed on filter paper squares for gel application. The major problem was keeping low temperature conditions during dissection of liver and eyes in small specimens under stereomicroscope. Therefore, liver and eye tissues were analyzed only to determine the percentage of polymorphic loci.

Horizontal electrophoresis with $11 \%$ starch gels (Starchart Corporation, Smithville, TX, USA) in continuous Tris-citrate buffer, was performed. Running times were $2-4 \mathrm{~h}$ at $40 \mathrm{~mA}$ under refrigeration $\left(1-4{ }^{\circ} \mathrm{C}\right)$. Staining techniques were partially modified from the original work of Harris and Hopkinson (1976).

A total number of 15 different gene-enzyme systems encoded in 24 loci in three different tissues yielded a good resolution and allowed interpretation Table 1. A locus was considered polymorphic when the most common allele frequency was lower than 0.95 . Genetic variability results are reported as observed heterozygosity at single polymorphic locus $\left(H_{\text {obs }}\right)$, mean heterozygosity at all loci $(H)$, and percentage of polymorphic loci $(P)$. Locus designation and nomenclature followed the system proposed by Shaklee et al. (1990). 


\subsection{AFLP analysis}

Genomic DNA was extracted and purified from small fragments of muscle tissue (about $0.5-1 \mathrm{~g}$ ) either according to the technique described by Moore (1999) or by means of the Aquapure genomic DNA kit (Biorad). After purification, 300-700 ng of genomic DNA were digested with EcoRI (rare cutter) and TaqI (frequent cutter) restriction endonucleases (Amersham Pharmacia Biotech, Milwaukee, WI) at two different times. Restriction was first carried out in a $25 \mu \mathrm{l}$ volume containing TaqI endonuclease (5 U), "one phor all buffer plus" (Amersham Pharmacia Biotech), $50 \mathrm{ng} / \mathrm{\mu l}$ of bovine serum albumin (BSA), $5 \mathrm{mM}$ dithiothreitol (DTT). After $1.5 \mathrm{~h}$ incubation at $65^{\circ} \mathrm{C}, 15 \mu \mathrm{l}$ of a solution containing $\operatorname{EcoRI}(5 \mathrm{U})$ and the same DTT, BSA and buffer composition was added to reach a final $40 \mu \mathrm{l}$ volume. Hence, the digestion was continued at $37{ }^{\circ} \mathrm{C}$ for $1.5 \mathrm{~h}$. Two separate restriction steps were carried out in relation to different optimal digestion temperatures of the endonucleases, and to avoid the rapid inactivation of $E c o R I\left(15 \mathrm{~min}\right.$ at $\left.60^{\circ} \mathrm{C}\right)$.

Ligation of synthetic adapters (Ajmone-Marsan et al., 1997) to the restriction fragments was carried out for $16 \mathrm{~h}$ at $16^{\circ} \mathrm{C}$ after adding $10 \mu \mathrm{l}$ of a solution containing $1 \mathrm{U}$ of T4 DNA Ligase (USB Cleveland, OH), EcoRI adapters (5 pmol), TaqI adapters (50 pmol), $1 \mathrm{mM}$ adenosine triphosphate (ATP), $5 \mathrm{mM}$ DTT, $50 \mathrm{ng} / \mu \mathrm{l} \mathrm{BSA}$ in "one phor all buffer plus" to the $40 \mu \mathrm{l}$ restriction solution. After ligation, the final $50 \mu \mathrm{l}$ reaction volume was diluted four times in sterile apirogen water.

Pre-amplification with primers Table 2 carrying one selective nucleotide (Vos et al., 1995; Ajmone-Marsan et al., 1997) was performed in $50 \mu \mathrm{l}$ volumes containing $15 \mu \mathrm{l}$ of diluted ligate (about 25-50 ng of template DNA), equal quantities of EcoRI and TaqI primers ( $75 \mathrm{ng}$ ), $0.2 \mathrm{mM}$ each of the four dNTPs, $1 \mathrm{U}$ of Taq polymerase (Roche Molecular Biochemical), $10 \mathrm{mM}$ Tris- $\mathrm{HCl}$ (pH 8.3), $1.5 \mathrm{mM} \mathrm{MgCl} 2,50$ $\mathrm{mM} \mathrm{KCl}$. The PCR reaction was carried out at the following amplification conditions: denaturation for $30 \mathrm{~s}$ at $94{ }^{\circ} \mathrm{C}$, annealing for $1 \mathrm{~min}$ at $56^{\circ} \mathrm{C}$, extension for $1 \mathrm{~min}$ at $72^{\circ} \mathrm{C}(30$ cycles), followed by $7 \mathrm{~min}$ at $72{ }^{\circ} \mathrm{C}$ to complete partial amplifications.

Preamplified template was diluted 30-50-fold with sterile apirogen water and $5 \mu \mathrm{l}$ of diluted product were further used for selective amplification (Vos et al., 1995; Ajmone-Marsan et al., 1997) in $20 \mu \mathrm{l}$ of PCR reaction mix containing EcoRI labeled (Cy5) primer (10 ng), unlabeled TaqI primer (30 ng), $1 \mathrm{U}$ of Taq polymerase (Roche Molecular Biochemical, Mannheim, Germany), $10 \mathrm{mM}$ Tris- $\mathrm{HCl}(\mathrm{pH} 8.3), 1.5 \mathrm{mM}$ $\mathrm{MgCl} 2,50 \mathrm{mM} \mathrm{KCl}, 0.2 \mathrm{mM}$ each of the four dNTPs. The selective amplification PCR profile was the following: $3 \mathrm{~min}$ at $94{ }^{\circ} \mathrm{C}, 11$ cycles of touch down reaction starting from $94{ }^{\circ} \mathrm{C} 30 \mathrm{~s}, 65^{\circ} \mathrm{C} 30 \mathrm{~s}\left(0.7^{\circ} \mathrm{C}\right.$ decrease at each cycle $), 72^{\circ} \mathrm{C}$ $2 \mathrm{~min}$ and additional 30 cycles at $94 \mathrm{C} 30 \mathrm{~s}, 56^{\circ} \mathrm{C} 30 \mathrm{~s}, 72^{\circ} \mathrm{C}$ $2 \mathrm{~min}$. Final extension of partial amplifications was reached at $72{ }^{\circ} \mathrm{C}$ for $30 \mathrm{~min}$.
Table 2

Sequences of restriction sites, adapters and primers used in the AFLP analyses

\begin{tabular}{lll}
\hline Name & \multicolumn{2}{c}{ Sequence } \\
\hline EcoRI & & GAATTC \\
TaqI & & CTTAAG \\
Adapters EcoRI & FW & ' \\
& & 5' CTCGA \\
Adapter TaqI & RW & 5' AATTGGTACGCAGTCTAC 3' \\
& FW & 5' GACGATGAGTCCTGAC 3' \\
Primers EcoRI & RW & 5' CGGTCAGGACTCAT 3' \\
& eA & 5' GACTGCGTACCAATTCA 3' \\
& eAAC & 5' GACTGCGTACCAATTCAAC 3' \\
& eAAG & 5' GACTGCGTACCAATTCAAG 3' \\
& eAGC & 5' GACTGCGTACCAATTCAGC 3' \\
& eAGT & 5' GACTGCGTACCAATTCAGT 3' \\
& eAGG & 5' GACTGCGTACCAATTCAGG 3' \\
& eAAT & 5' GACTGCGTACCAATTCAAT 3' \\
& eACG & 5' GACTGCGTACCAATTCACG 3' \\
& eACT & 5' GACTGCGTACCAATTCACT 3' \\
& eAAT & 5' GACTGCGTACCAATTCAAT 3' \\
& eACA & 5' GACTGCGTACCAATTCACA 3' \\
& tA & 5' GATGAGTCCTGACCGAA 3' \\
& tC & 5' GATGAGTCCTGACCGAC 3' \\
& tAAC & 5' GATGAGTCCTGACCGAAAC 3' \\
& tAAG & 5' GATGAGTCCTGACCGAAAG 3' \\
& tACG & 5' GATGAGTCCTGACCGAACG 3' \\
& tCCT & 5' GATGAGTCCTGACCGACCT 3' \\
& tCAT & 5' GATGAGTCCTGACCGACAT 3' \\
& tCAG & 5' GATGAGTCCTGACCGACAG 3' \\
\hline & &
\end{tabular}

A $1.5 \mu \mathrm{l}$ volume of PCR product and $0.5 \mu \mathrm{l}$ of DNA internal size standards (CEQ DNA Size standard-600 Beckman-Coulter, Fullerton, CA) were added to $40 \mu \mathrm{l}$ of deionized formamide (J.T. Baker, Phillipsburg, NJ). Samples were then loaded into the $\mathrm{CEQ}^{\mathrm{TM}} 2000$ DNA Analysis System, an automatic sequencer equipped with a $33 \mathrm{~mm}$ separation capillary array (eight capillaries). Running conditions were: template denaturation for $120 \mathrm{~s}$ at $90^{\circ} \mathrm{C}$, injection time $110 \mathrm{~s}$ at $2 \mathrm{kV}$, fragments separation for $50 \mathrm{~min}$ at $6 \mathrm{kV}$.

After determination of fragment sizes obtained by comparison with internal size standards (CEQ WellRED fluorescent dye), AFLP markers were then examined by means of Genographer software (Vers.1.6.0, Benham J.J., Montana State University, 2001) and exported to standard graphical formats essential for phylogenetic analyses.

\subsection{Data analysis}

Allozyme results were elaborated with the computer program Biosys-1 (Swofford and Selander, 1981) to determine allelic frequencies, heterozygosity values, deviations from the Hardy-Weinberg equilibrium, Nei's genetic distances and F-statistics (Nei, 1987).

Scoring of AFLP markers was performed assigning 0 as band absence and 1 as band presence. Each band of a defined molecular size was assumed to be a discrete locus. Only the fragments in the range 70-600 bp were considered. Genetic 
Table 3

Comparison of allozyme and AFLP polymorphisms in L. saliens and L. ramada, other Mugilidae and ecologically similar species

\begin{tabular}{|c|c|c|c|c|c|}
\hline \multicolumn{6}{|c|}{ Gene-enzyme systems } \\
\hline Author & Species & Number of systems & Number of loci & $P$ & $H$ \\
\hline \multirow[t]{2}{*}{ Present work } & L. saliens & 24 & 15 & $8 \%$ & $1.6-2.2 \%$ \\
\hline & L. ramada & 24 & 15 & $8 \%$ & $1-2 \%$ \\
\hline Rossi et al., 1998b & M. cephalus & 21 & 27 & $0-26 \%$ & $5 \%$ \\
\hline \multirow[t]{5}{*}{ Rossi et al., 1998a } & $\begin{array}{l}\text { Five species of } \\
\text { Mugilidae }\end{array}$ & 15 & 18 & & \\
\hline & Mugil curema & - & - & $27 \%$ & - \\
\hline & Mugil gyrans & - & - & $17 \%$ & - \\
\hline & L. ramada & - & - & $17 \%$ & - \\
\hline & Xenomugil thoburni & & & $11 \%$ & - \\
\hline \multirow[t]{6}{*}{ Papasotiropoulos et al., 2001} & $\begin{array}{l}\text { Five species of } \\
\text { Mugilidae }\end{array}$ & 12 & 22 & & \\
\hline & M. cephalus & - & - & $9.1 \%$ & $2 \%$ \\
\hline & Chelon labrosus & - & - & $13.6 \%$ & $6.9 \%$ \\
\hline & L. saliens & - & - & $18.2 \%$ & $2.6 \%$ \\
\hline & Liza aurata & - & - & $18.2 \%$ & $5.1 \%$ \\
\hline & L. ramada & - & - & $31.8 \%$ & $3.7 \%$ \\
\hline Miller et al., 1994 & K. panizzae & 12 & 18 & $17 \%$ & $5.3 \%$ \\
\hline Maltagliati, 1999 & A. fasciatus & 22 & 43 & $2-21 \%$ & $1.2-6 \%$ \\
\hline Nevo et al., 1984 & Review 186 species & - & - & $21 \%$ & $5.5 \%$ \\
\hline Smith and Fujio, 1982 & Review 89 species & - & - & - & $6 \%$ \\
\hline Kirpichnikov, 1992 & Review & - & - & $20 \%$ & $5 \%$ \\
\hline
\end{tabular}

\begin{tabular}{|c|c|c|c|c|c|}
\hline \multicolumn{6}{|c|}{ AFLP } \\
\hline Author & Species & $\begin{array}{l}\text { Number of primer } \\
\text { combinations }\end{array}$ & Number of loci total & $\begin{array}{l}\text { Number of loci } \\
\text { polymorphic }\end{array}$ & $P$ \\
\hline \multirow[t]{2}{*}{ Present work } & L. saliens & 15 & 529 & 165 & $30.3 \%$ \\
\hline & L. ramada & 4 & 220 & 82 & $35.0 \%$ \\
\hline Seki et al., 1999 & P. altivelis & 19 & 745 & 276 & $55.0 \%$ \\
\hline Liu et al., 1999 & Ictalurus punctatus & 64 & 7871 & 3081 & $40.0 \%$ \\
\hline
\end{tabular}

variation of each sample was assessed on the basis of estimated proportion of polymorphic loci, that is the ratio between variable and total loci. In addition, the Band Sharing Index (Lynch, 1990) to define the degree of similarity among different groups, was calculated by means of the R-package (available at http://www.r-project.org/).

\section{Results}

\subsection{Allozyme data}

Analyses of allozyme variability at 24 genetic loci revealed a generally low level of biochemical polymorphisms in both taxa. The three loci GPI-A, GPI-B and G3PDH were the only polymorphic systems in $L$. saliens and $L$. ramada Table 1. GPI-A was variable only in L. saliens while GPI-B was polymorphic only in $L$. ramada. The percentage of polymorphic loci $(P)$ determined in all samples was $8 \%$. The observed mean heterozygosity $(H)$ ranged between 0.016 and 0.022 in L. saliens and was in the range 0.010 and 0.020 in $L$. ramada. As a matter of comparison, the ecologically similar sympatric species Knipowitschia panizzae (Gobiidae) and Aphanius fasciatus (Cyprinodontidae) have higher $H$ and $P$-values than $L$. saliens and $L$. ramada Table 3 .
In relation to the adaptive role of heterozygosity, the attention was deserved to the GPI system according to its metabolic importance in Mugilidae (Huang et al., 2001). Observed heterozygosity values for GPI-A in L. saliens did not show significant variations in relation to fish growth. In this case, variations of $H_{\text {obs }}$ between 0.045 and 0.090 were scarcely correlated to the fish sizes (correlation index $r=$ 0.70). Slight differences of mean heterozygosity values in samples collected at different times of the year, were observed.

$F_{\text {IS }}$ values for pairwise comparisons among $L$. saliens samples collected during different months at the Spiaggina and Pre Valle sites were 0.353-0.360. These values evidence a general enhanced intrapopulation inbreeding level. Differentiation between Spiaggina and PreValle groups was negligible as demonstrated by $F_{\mathrm{ST}} 0.007$, and Nei's unbiased genetic distance $D=0$ supporting the observation of elevated similarity in the L. saliens population of the whole embayment, and no subpopulation structuring.

From a taxonomic point of view, juveniles of both the thinlipped and sharpnose mullets at different life stages are hardly distinguishable using morphological characters. Therefore, biochemical analyses supported species identification. A number of loci were diagnostic to assess the taxonomic characterization of juveniles. In particular, the GPI-A, 


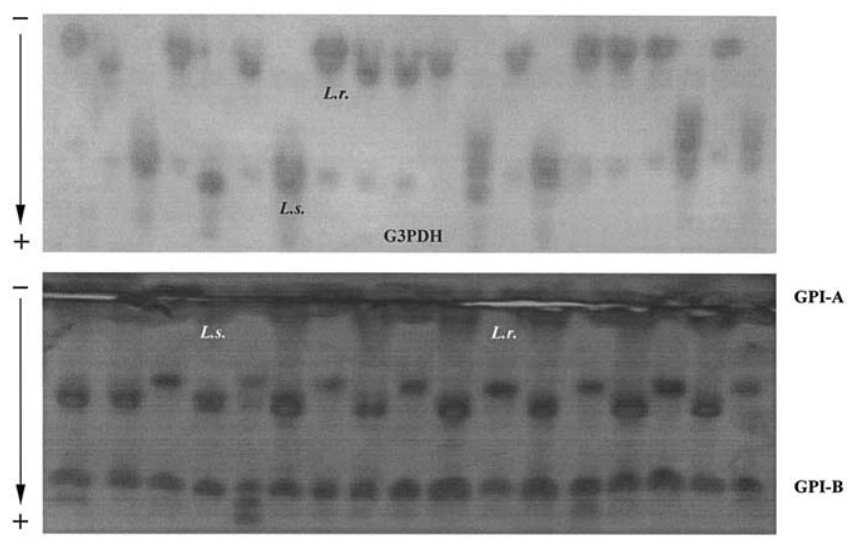

Fig. 3. Diagnostic electromorphs of the GPI (bottom) and G3PDH (top) systems to assess species identification.

G3PDH, AK-2, CK-A, CK-B, AAT, IDH, PGM-1, PGM-2 loci did not show shared alleles in pairwise comparisons between species, and were, therefore, useful in systematics. Reference samples submitted to biochemical analyses were identified according to the number of pyloric caeca and pigmentation following the classification of mullet fry proposed by Serventi et al. (1996). In Fig. 3 diagnostic alleles of the GPI and G3PDH systems for species discrimination, are illustrated.

\subsection{AFLP data}

Fifteen primer combinations generated 529 DNA fragments in L. saliens 165 of which were polymorphic. The number of fragments per primer combination ranged from 9 to 74 (mean: 35.27). A lower number of primer combinations were tested in $L$. ramada. Four primer combinations generated 220 DNA fragments in this species, 82 of which were variable. The frequency of polymorphic loci $(P)$ in $L$. saliens was in the range $0.11-0.43$ (mean value 0.303 ), whereas $P$ ranged between 0.10 and 0.48 in $L$. ramada (mean value 0.350 ). Primer combinations and AFLP data in L. saliens are reported in Table 4.

In agreement with allozyme data, levels of AFLP variation were generally lower than the ones described in other fish species Table 3. It must be pointed out that application of the AFL $\mathrm{P}$ methodology to fishery management is very recent, and only a few papers (Liu et al., 1999; Seki et al., 1999) are nowadays available. Hence, comparisons can be made only with phylogenetically distant species. In this case, the most appropriate comparison could be made with data on amphidromous populations of ayu Plecoglossus altivelis (Seki et al., 1999).

An interesting question is whether or not AFLP markers are a helpful tool to assess genetic differences at intraspecific level in migratory species. The BSI calculated considering pairwise comparisons of all loci in both groups ranged between 0.93 and 0.95 (0.82-0.85 considering only the polymorphic loci). A statistically significant difference $(P=$ $1.86 E-32$, standard error 0.0005 ) among the group entering the lagoon and the one returning to the sea, was therefore, observed. The frequency distribution of BSI values in the two groups is illustrated in Fig. 4 Two distinct distributions suggest a certain degree of separation between the entering population of sharpnose mullets and the one leaving the Sacca di Goro.

Species-specific bands were identified using different primer combinations, and were used for taxonomic identification. In Fig. 5 diagnostic loci to differentiate $L$. saliens and L. ramada, are presented. Reference specimens were identified according to the above cited Serventi et al. (1996).

Table 4

Primer combinations and AFLP polymorphism values in L. saliens

\begin{tabular}{|c|c|c|c|c|c|c|}
\hline \multicolumn{7}{|c|}{ AFLP markers } \\
\hline Combination number & $\begin{array}{l}\text { Selective } \\
\text { nucleotides (primer } \\
\text { combinations) }\end{array}$ & $\begin{array}{l}\text { Number of total } \\
\text { fragments }\end{array}$ & $\begin{array}{l}\text { Number of } \\
\text { polymorphic } \\
\text { fragments }\end{array}$ & $\begin{array}{l}\text { Number of fixed } \\
\text { fragments }\end{array}$ & $\begin{array}{l}\text { Frequency of } \\
\text { polymorphisms }\end{array}$ & \\
\hline & EcoRI & TaqI & & & & \\
\hline 1 & AGT & ACG & 15 & 4 & 11 & 0.26 \\
\hline 2 & AGG & ACG & 31 & 7 & 24 & 0.22 \\
\hline 3 & AAT & ACG & 23 & 8 & 15 & 0.35 \\
\hline 4 & $\mathrm{ACA}$ & ACG & 31 & 8 & 23 & 0.26 \\
\hline 5 & ACG & ACG & 9 & 3 & 6 & 0.33 \\
\hline 6 & AGC & AAG & 51 & 18 & 43 & 0.35 \\
\hline 7 & AAG & AAG & 37 & 16 & 21 & 0.43 \\
\hline 8 & AAT & $\mathrm{CCT}$ & 26 & 8 & 18 & 0.31 \\
\hline 9 & AGT & $\mathrm{CCT}$ & 35 & 4 & 31 & 0.11 \\
\hline 10 & AGC & $\mathrm{CCT}$ & 35 & 6 & 29 & 0.17 \\
\hline 11 & $\mathrm{ACT}$ & CCT & 40 & 13 & 27 & 0.32 \\
\hline 12 & AGC & CAT & 40 & 15 & 25 & 0.37 \\
\hline 13 & AAC & CAG & 37 & 15 & 22 & 0.41 \\
\hline 14 & AGC & $\mathrm{AAC}$ & 74 & 25 & 49 & 0.34 \\
\hline 15 & AAC & $\mathrm{AAC}$ & 45 & 15 & 30 & 0.33 \\
\hline Total values & & & $=529$ & $=165$ & $=374$ & Mean $P=0.30$ \\
\hline
\end{tabular}




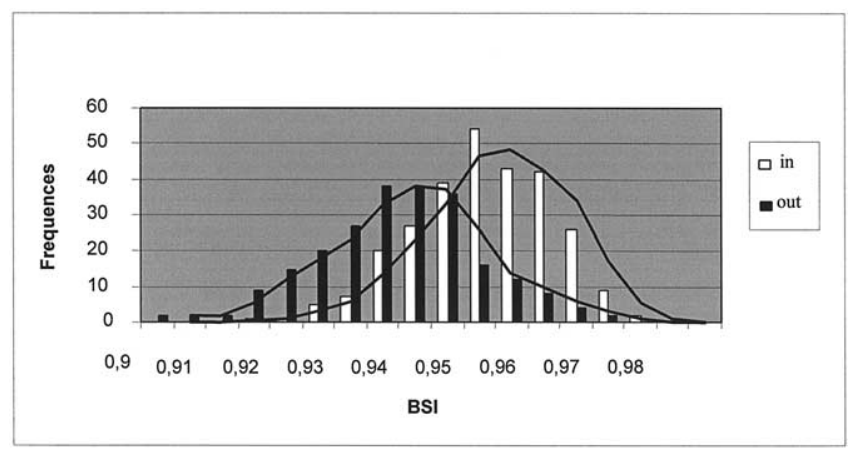

Fig. 4. Frequency distribution of band sharing index (BSI) in the inland migrating $L$. saliens population and the one returning to the sea.

\section{Conclusions}

The genetic homogeneity found in the thinlipped ( $L$. ramada) and the sharpnose (L. saliens) mullets reflects the pattern of morphological uniformity highlighted in the two species. The degree of genetic variation presented by the two species is certainly on the low side, despite their generalisteasy adaptable characteristics. Both mullets exhibited average heterozygosity values $(H=0.010-0.022)$ lower than the ones (0.05-0.06) given as an average for marine teleosts (Smith and Fujio, 1982; Kirpichnikov, 1992). Comparisons with ecologically similar euryhaline species demonstrated that in spite of similar habitats and ecological attitudes, levels of genetic variation are very different among $r$-selected species.

Low $H$ values have also been found by other investigators in several mullet species (Menezes et al., 1992; Rossi et al., 1998a). In particular, Rossi et al. (1998a) and Papasotiropoulos et al. (2001) reported wide ranges of allozyme variation: $P=4-17 \%$ and $H=0.018-0.081, P=18-36 \%$ and $H=$ 0.026-0.036, respectively, in the striped mullet $M$. cephalus

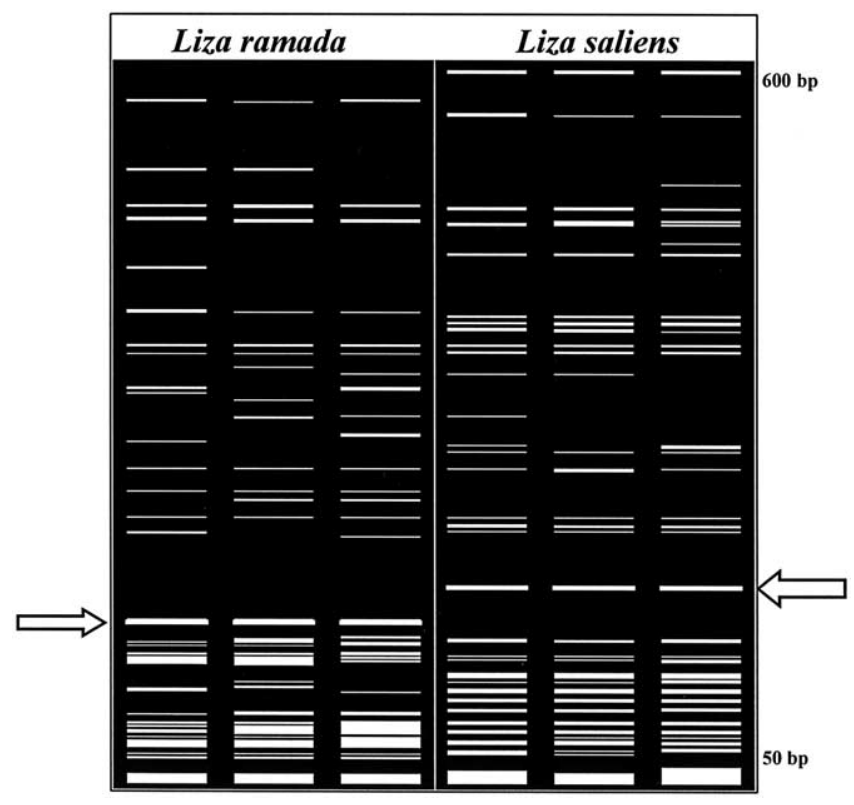

Fig. 5. Genographer representation of AFLP diagnostic loci to identify unknown juveniles of $L$. saliens and L. ramada. and in Liza spp. The low values of both heterozygosity and polymorphic loci found in the sharpnose and thinlipped mullets from the Po river coastal lagoons could be explained by genetic drift or by directional selection as a consequence of limited spawning areas. The samples homogeneity inside the lagoon is certainly referred to the schooling behavior of the species. In addition, enhanced consanguineity as demonstrated by $F_{\text {IS }}$ values is probably due to limited breeding areas forelying the Sacca di Goro and scarce interpopulations gene flow among Adriatic spawning sites. As a matter of fact, deviations from Hardy-Weinberg equilibrium due to heterozygotes deficit at the three loci in both Liza species, were observed at the time of inland migration. Rossi et al. (1998a, b) have already indicated absence of significant gene flow in mullet species at macro-geographic level. Although data on mullet fisheries is not available, it could also be supposed that bottleneck effects might be generated by over-fishing due to the economic importance of the mullets. As a matter of fact, the two species are largely exploited in the North Adriatic area.

It is noteworthy to observe that Papasotiropoulos et al. (2001) suggested that differences among $H_{\text {obs }}$ values found by various investigators may be due to differences in populations dynamics. In this work evidence emerges that differences may also be due to taxonomic misinterpretations of sympatric populations, especially in the case of juvenile mullets. Fixed alleles of the GPI, G3PDH, AK, CK, AAT, IDH and PGM systems are helpful to determine the presence of different species but results can be trivial if more than two species are present at the same time. In the Adriatic coastal lagoons identification of the five mullet species based on allozyme allelic differences could be difficult in the periods of contemporary migration.

Although species identification can usually be performed with allozymes, the advantage of using AFLP markers is that loci are easy to detect and many loci can be scored at the same time. Therefore, AFLP can certainly be of major help to understand genetic relationships both at the intraspecific and the interspecific level (Seki et al., 1999). In particular, a general concordance between allozyme and AFLP data, was proved. Levels of AFLP variation $(P=0.30-0.35)$ were generally lower than the one described in another euryhaline species (0.55). It must be remarked that application of the AFLP methodology to animal science is quite recent, and a few papers are available on fish (Liu et al., 1999; Seki et al., 1999).

Diagnostic AFLP species-specific bands were identified, and it was proved that species identification can be carried out with just one primer combination. Using many primersets can be useful in examining variations of genetic diversity at the intrapopulation level. Although being dominant markers not allowing direct determination of heterozygosity values, allelic dynamics in the L. saliens population were used to assess seasonal intra-population differences. According to BSI indexes, genetic differences between inland migrating Liza populations and the ones returning to the sea, were 
demonstrated. Whether or not they can be referred to natural selection or genetic drift, has to be further investigated.

Considering the many doubts still existing on the taxonomy and ecology of mullet species, we believe that additional molecular investigations, are necessary. In particular, the distribution and seasonal dynamics of AFLP patterns in all five Mugilidae species entering the Adriatic coastal lagoons should be assessed.

\section{Acknowledgements}

The research was supported by Ministry of University Science and Technology-Cofin grants 1999. Project "Production, change and vulnerability of transitional aquatic environments along the Adriatic coast", National coordinator Professor I. Ferrari.

\section{References}

Ajmone-Marsan, P., Valentini, A., Cassandro, M., Vecchiotti-Antaldi, G., Bretoni, G., Kuiper, M., 1997. AFLP markers for DNA fingerprinting in cattle. Anim. Genet. 28, 418-426.

Britten, H.B., 1996. Meta-analyses of the association between multilocus heterozygosity and fitness. Evolution 50, 2158-2164.

Caldara, F., Bargelloni, L., Ostellari, L., Penzo, E., Colombo, L., Patarnello, T., 1996. Molecular phylogeny of grey mullets based on mitochondrial DNA sequence analysis: evidence of differential rate of evolution at the intrafamily level. Mol. Phylogenet. Evol. 6, 416-424.

Carvalho, G.R., Hauser, L., 1998. Advances in the molecular analysis of fish population structure. Ital. J. Zool. 65, 21-33.

Crosetti, D., Nelson, W.S., Avise, J., 1994. Pronounced genetic structure of mitochondrial DNA among populations of the circumglobally distributed grey mullet (Mugil cephalus Linnaeus). J. Fish Biol. 44, 47-58.

David, P., 1998. Heterozygosity-fitness correlations: new perspectives on old problems. Heredity 80, 531-537.

Harris, H., Hopkinson, D.A., 1976. Handbook of Enzyme Electrophoresis in Human Genetics. North Holland Publishing Company, Amsterdam, Holland.

Huang, C.S., Weng, C.F., Lee, S.C., 2001. Distinguishing two types of gray mullet, Mugil cephalus L. (Mugiliformes: Mugilidae), by using glucose6-phosphate isomerase (GPI) allozymes with special reference to enzyme activities. J. Comp. Physiol. B 171, 387-394.

Kirpichnikov, V.S., 1992. Adaptive nature of intrapopulational biochemical polymorphism in fish. J. Fish Biol. 40, 1-16.

Liu, X., Li, P., Kucuktas, H., Nichols, A., Tan, G., Zheng, X., Argue, B.J., Dunham, R.A., 1999. Development of amplified fragment length polymorphism (AFLP) markers suitable for genetic linkage mapping of catfish. Trans. Am. Fish. Soc. 128, 317-327.

Lynch, M., 1990. The similarity index and DNA fingerprinting. Mol. Biol. Evol. 7, 478-484.

Maltagliati, F., 1999. Genetic divergence in natural populations of the Mediterranean brackish-water killifish Aphanius fasciatus. Mar. Ecol. P.S. 179, 155-162.

Menezes, M.R., Martins, M., Naik, S., 1992. Interspecific genetic divergence in grey mullets from the Goa region. Aquaculture 105, 117.
Miller, P.J., Serventi, M., Soregaroli, P., Torricelli, P., Gandolfi, G., 1994. Isozyme genetics and the phylogeny of Italian freshwater gobies (Teleostei: Gobioidei). J. Fish Biol. 44, 439-451.

Mitton, J.B., 1998. Molecular markers and natural selection. Adv. Mol. Ecol. 306, 225-241.

Moore, D., 1999. Manipulation of DNA. Current Protocols in Molecular Biology. Wiley, New York, pp. 2.1.1-2.2.3.

Nei, M., 1987. Genetic distance between populations. Molecular Evolutionary Genetics. Columbia University Press, New York, pp. 208-254.

Nelson, J.S., 1994. Fishes of the World. Wiley, New York.

Nevo, E., Beiles, A., Ben Schlomo, R., 1984. The evolutionary significance of genetic diversity. Lecture Notes in Biomathematics, vol. 53. Springer, Berlin, pp. 13-213.

Papasotiropoulos, V., Klossa-Kilia, E., Kilias, G., Alahiotis, S., 2001. Genetic divergence and phylogenetic relationships in grey mullets (Teleostei: Mugilidae) using allozyme data. Biochem. Genet. 39, 155-168.

Parker, P.G., Snow, A.A., Schug, M.D., Booton, G.C., Fuerst, P.A., 1998. What molecules can tell us about populations: choosing and using a molecular marker. Ecology 79, 361-382.

Rossi, A.R., Capula, M., Crosetti, D., Sola, L., Campton, D.E., 1998a. Allozyme variation in global populations of striped mullet, Mugil cephalus (Pisces: Mugilidae). Mar. Biol. 131, 203-212.

Rossi, A.R., Capula, M., Crosetti, D., Campton, D.E., Sola, L., 1998b. Genetic divergence and phylogenetic inferences in five species of Mugilidae (Pisces: Perciformes). Mar. Biol. 131, 213-218.

Savelkoul, P.H.M., Aarts, H.J.M., De Haas, J., Dijkshoorn, L., Duim, B., Otsen, M., Rademaker, J.L.W., Schouls, L., Lenstra, J.A., 1999. Amplified fragment length polymorphism analysis: the state of the art. J. Clin. Microbiol. 37, 3083-3091.

Seki, S., Agresti, J.J., Gall, G.A.E., Taniguchi, N., May, B., 1999. AFLP analysis of genetic diversity in three populations of ayu Plecoglossus altivelis. Fish. Sci. 65, 888-892.

Serventi, M., Harrison, I.J., Torricelli, P., Gandolfi, G., 1996. The use of pigmentation and morphological characters to identify Italian mullet fry. J. Fish Biol. 49, 1163-1173.

Shaklee, J.B., Allendorf, F.W., Morizot, D.C., Whitt, G.S., 1990. Gene nomenclature for protein coding loci in fish. Trans. Am. Fish. Soc. 119, 2-15.

Smith, P.J., Fujio, Y., 1982. Genetic variation in marine teleosts: high variability in habitat specialists and low variability in habitat generalists. Mar. Biol. 69, 7-20.

Swofford, D.L., Selander, R.B., 1981. BIOSYS-1: a FORTRAN program for the comprehensive analysis of electrophoretic data in population genetics and systematics. J. Hered. 72, 281-283.

Tsitrone, A., Rousset, F., David, P., 2001. Heterosis, marker mutational processes and population inbreeding history. Genetics 159, 1845-1859.

Viaroli, P., Azzoni, R., Bartoli, M., Giordani, G., Tajè, L., 1999. Evolution of the trophic conditions and dystrophic outbreaks in the Sacca di Goro lagoon (Northern Adriatic Sea). In: Faranda, F.M., Guglielmo, L., Spezie, G. (Eds.), Mediterranean Ecosystems: Structures and Processes. Springer, Berlin, pp. 467-475.

Vos, P., Hogers, R., Bleeker, M., Reijans, M., Van de Lee, T., Hornes, M., Frijters, A., Pot, J., Peleman, J., Kuiper, M., Zabeau, M., 1995. AFLP: a new technique for DNA fingerprinting. Nucleic Acids Res. 23, 4407-4414.

Ward, R.D., Grewe, P.M., 1994. Appraisal of molecular genetic techniques in fisheries. Rev. Fish. Biol. Fisher. 4, 300-325. 